\title{
IN-TEXT TRANSLATION IN THE GERMAN AND YORUBA BIBLES: CONVERGENCE OR DIVERGENCE?
}

\author{
Omotayo Ibukun Fakayode \\ Department of Linguistics and Language Practice \\ University of the Free State
}

\begin{abstract}
The Bible is currently being retranslated into German and Yoruba. It is, however, noteworthy that the comparison between the German and Yoruba Bibles has enjoyed minimal attention from scholars of Bible translation. In view of this, the present paper examines the in-text translations in the four gospels of the New Testament of three German and three Yoruba versions of the Bible. The result shows that even though the German versions of the Bible have the same source text, there is a divergence in the transfer of in-text translation, while in the Yoruba versions, the transfer of in-text translation is less divergent despite the fact that these are retranslations of different English versions which were used as source texts.
\end{abstract}

Keywords: bible translation; German; retranslation; Yoruba

\section{Introduction}

Multilingualism, which is a common phenomenon in African and Asian societies, has also been practised in literary works over time. The Bible, which was written by multilingual individuals, is not exempt from this practice. As a result, the effect of multilingualism, including "code-switching ", ${ }^{1}$ is very much evident in the gospels of the New Testament of the Bible. Authors who code-switch in literary work, sometimes resolve into "in-text translation" (Achebe 1959:1964). In-text translation is a technique employed by multilingual writers to clarify non-native words used in code-switched text. For example, Bandia (1996:141) describes in-text translation as "an attempt to clarify the meaning of a foreign language word, expression, clause or sentence within an utterance which is otherwise entirely in the main language of writing or expression. This translation technique seeks to elucidate foreign language items in an utterance by providing clarification within one and the same discourse". Bandia's definition of in-text translation can be understood to be limited to words that are "foreign". However, the term "foreign" could be inappropriate, considering the fact that some words in another language may not be completely foreign in a community in situations of proximity between the community and the speakers of the language. This is the case with Hebrew in the New Testament (NT), which was originally written in Greek. In-text translation can also mean the translation or explanation of a word before or after a non-native word in a text with the purpose of further clarifying the meaning of the word for the reader. This concept of "non-native" rather than "foreign" will be employed in this study.

Code-switching is a linguistic term which describes a situation where two distinct languages are used concurrently within a single conversation (see Gumperz 1982). 
Various studies have focused on the translation of the Bible into African languages (Masubelele 2007; Oyali 2016) and some studies have also focused on comparing Bible translations in European and African languages (Makutoane and Naudé 2009). As regards the comparison between German and Yoruba Bibles, Oyebola (2008) examined the linguistic aspects of the translation of the Bible into Yoruba. By comparing the German (LB), English (KJV), and Yoruba (BM) translations of the Bible, he established that the fact that English is the source language for the Yoruba Bible has a huge influence on the language and the message of the Yoruba Bible. This influence is, to a large extent, in contrast to the German Bible, which was directly translated from the source languages. To complement these past studies, I shall focus on the examination of in-text translations in the Bible in terms of a comparison between the German and the Yoruba Bibles. To do this, I shall employ Newmark's semantic and communicative theory of translation (1981; 1988) and the retranslation hypothesis. The first observation in this analysis is that, after a close examination of the data, the German retranslations of the Bible demonstrate a communicative approach while the Yoruba retranslations of the Bible are semantic. As Newmark (1981:39) states,

Communicative translation attempts to produce on its readers an effect as close as possible to that obtained on the readers of the original. Semantic translation attempts to render as closely as the semantic and syntactic structures of the second language allow the exact contextual meaning of the original.

Munday (2010) criticises Newmark's semantic and communicative theory of translation as resembling Eugene Nida's theory of formal and dynamic equivalence respectively (Nida 1947). However, Newmark dissociates himself from Nida's theory of equivalence, claiming that the equivalence effect "is inoperant if the text is out of TL (Target Language) space and time" (1981:69). Bearing this in mind, Newmark's theory is more applicable in examining the (re)translations of the Bible than Nida's formal and dynamic equivalence. This is because these translations take place over a very long period. Given this, the Retranslation Hypothesis theory (RH) promoted by Newmark becomes relevant for the study. More importantly, the fact that in-text translations are translations in the original already posits a kind of interpretation, and working with various translations of the Bible in a single language will reveal the different interpretations of the in-text translations.

As such, this study intends to examine and compare the transfer of certain in-text translations into the German and Yoruba Bibles. This will indicate whether there is a convergence or divergence in the (re)translations of the non-native words in the NT gospels. The three German versions of the Bible to be examined are Martin Luther Bibel (MLB), Hoffnung für Alle (HFA), and Gute Nachricht Bibel (GNB), and the three Yoruba Bible translations are Bibeli Mimo (BM1), Bibeli Mimo (BM2), and Bibeli Iroyin Ayo (BIA).

According to RH theory, retranslations are closer to the source text than first translations, which are oriented towards the target culture. Thus, first translations serve as the domesticating phase. Discussing retranslation, Bensimon (1990) refers to first translations as "naturalization of the foreign works", which serves to introduce them to a given target culture, to integrate one culture into the other, and ensure that the work is 
received in the target culture. Subsequent translations, however, tend to pay more attention to the letter and style of the source. In the light of the above, it is assumed that the first translations of the German and Yoruba Bibles (MLB and BM1) are more communicative in their approach than subsequent versions, which will be explored further in this article.

\section{German translations of the Bible}

The German Bibles were translated from the original, which was written in Hebrew and Greek (Folsom 1986), and that means that all the German versions have only one source text, which is also the original. Since the comparison with the source text is beyond the concern of this study, the first and subsequent translations of the German Bible will only be compared to indicate points of differences.

Although consistency in the in-text translation of foreign words in the gospels cannot be judged in the first German version since there is no previous German translation, one could say that domestication occurs in the reproduction of alien words in this version. For example, the following texts read:
Hefata!, das heißt: Tu dich auf! (Mark 7:34)
(Hefata! That means: You yourself open - back translation)
(Hefata! Which means: open! - my translation)
... die da heißt Schädelstätte auf hebräisch Golgatha (John 19:17)
(... the there means skullplace in Hebrew Golgotha - back translation)
(which means place of skull, in Hebrew Golgotha - my translation)

In the GNB, the words are spelled "Ephaphatha" and "Golgotha", as compared to the English version, in which they are spelled "Effata" and "Golgota". The addition of "h" to "Efata" and the changing of "o" to "a" in "Golgotha" for easy pronunciation by the Germans show a form of domestication in the first German version.

A close examination of the in-text translation of non-native words in the HFA German translation of the Bible shows that it is characterised by over-translation, omission, and domestication of the foreign word. It also employs a writing strategy of rendering the foreign words in brackets. These four strategies demonstrate an attempt to communicate better with the target readers by more or less avoiding the foreign words so as not to disturb the flow of reading. For example, over-translation occurs in Mark 5:9, where the translation states:

\section{Mein Name ist Legion, denn viele von uns beherrschen diesen Menschen (My name is Legion, for many of us rule this man) \\ (My name is Legion, for many of us have dominion over this man)}

This would be considered over-translation because the word "legion" actually means "many" and not "dominate". The omission of alien words is the most common strategy in this translation. In this version the following words are omitted: "Korban" (Mark 7:11), "Effata" (Mark 7:34), "Kephas" (John 1:42), "Rabbi” (John 1:38), and "Boanerges" (Mark 3:17). The HFA version also uses the domestication strategy in John 
19:17 by translating "Golgotha" as "Golgatha". In this version the translation of the word "Siloam" in John 9:7 is in brackets, indicating a deliberate attempt not to disturb the flow of reading. The four strategies mentioned in the examples show that a more communicative approach was employed in the translation of HFA than in MLB.

The third German translation of the Bible used for this study indicates that explicitation, omission, and domestication together with foreignisation were used in the transfer of non-native words and their in-text translations. For example, the following passages in GNB read:

Legion. Wir sind nämlich viele! (Mark 5:9)

(Legion. We are namely many! - back translation)

(Legion. We are really many! - my translation)

Korban - das heißt: was ihr von mir bekommen müßtet, ist für Gott bestimmt (Mark 7: 11)

(Korban - that means: what you from me receive must, is for God determined back translation)

(Korban - which means: what you should get from me is meant for God - my translation)

Kephas ist das hebräische Wort für Petrus (John 1: 42)

(Kephas is the Hebrew word for Peter - back/my translation)

These examples show a form of explicitation with words and phrases like nämlich, was ihr von mir bekommen müßtet, and das hebräische Wort. The omission of the alien word occurs in only one of the examples identified in the study of the GNB, and that is in Mark 3:17, which reads:

\section{Jakobus und sein Bruder Johannes, die er Donnersöhne nannte}

(James and his brother John, that he thundersons named - back translation)

(James and his brother John, that he named sons of thunder - my translation)

It is, however, interesting to note that the foreignisation and domestication methods occur in the transfer of the non-native words in this version. For example, Matthew 1:23 contains the word "Immanuël". The letter "ë" is not in the German alphabet, indicating foreignisation. However, the word "Schiloach" appears in John 9:7, making use of a typically German spelling. This is domestication. Therefore, the translators did not resolve to use only one strategy when transferring foreign words into German.

From the above it can be deduced that the different German translations of the Bible, although they have the same source text, differ in their approach to transferring nonnative words and their in-text translations. The new translations also prove to be more communicative in strategy, indicating that the retranslations are more target languageoriented, contrary to the claim of RH theory. 


\section{Yoruba translations of the Bible}

The Yoruba translations of the Bible are retranslations of the English Bible. As a result, there is more than one source text for the Yoruba Bible because there are many English versions of the Bible. For example, the first Yoruba Bible, Bibeli Mimo (BM), was translated from the King James Version (KJV) of the English Bible, while Bibeli Iroyin Ayo (BIA) was translated from the Good News Bible (GNB).

It can be observed that BM1 is characterised by foreignisation and formal equivalence, the second translation, BM2, also by foreignisation, and the third translation, BIA, is characterised by domestication, dynamic equivalence, and explicitation. It is, however, worth noting that the first and second translations are quite similar since the second translation is a revision of the first, although foreignisation occurs more frequently in the second translation than in the first translation. For example, foreignisation occurs in both target texts as alien words are spelt the English way, e.g. "Emmanueli" (Matt 1:23), "Korbani" (Mark 7:11), and "Sabaktani" (Matt 15:34). Whereas in the third translation these words are spelt "Imanuelli", "Kobani", and "Sabakitani". The third translation shows a form of domestication of the words since Yoruba does not grammatically allow consonant clusters as in "Korbani" and "Sabaktani". Besides, the letter "e" should be replaced with " $i$ " if the word "Emmanuel" is pronounced correctly in Yoruba.

Likewise, formal equivalence occurs in the first two translations in the following examples:

Emmanueli, itumo eyi ti ise, Olorun wa pelu wa (Matt 1:23)

(Emmanuel, meaning which marker makes, God is with us - back translation)

(Emmanuel, which means, God is with us - my translation)

\section{Talita kunmi, itumo eyi ti ije omobinrin, mo wi fun o, Dide (Mark 5:41)}

(Talita kunmi, meaning which marker means girlchild, I say to you, Rise - back translation)

(Talita kunmi, which means little girl I say unto you, Arise - my translation)

These examples demonstrate that the Yoruba translations of the foreign words and their in-text translations follow the syntactic structure of the English language. In contrast to this, the third Bible translation is more dynamic and communicative. The first example in Matthew 1:23 uses the word "omode" and not "omobirin". "Omobirin" is a syntactic translation of "young girl" introduced into the Yoruba language through Bible translation. Moreover, the in-text translation is placed in brackets in many instances in BIA. In this translation these two examples read as follows:

Imanueli (itumo "Imanueli" ni "Olorun wa pelu wa") (Matt 1:23)

(Emmanuel (meaning "Emmanuel" is "God is with us") - back translation)

(Emmanuel (the meaning of "Emmanuel" is "God is with us") - my translation)

"Talita kuni", itumo eyi ti ise, "iwo omode yii, mo wi fun o, died" (Mark 4:41) ("Talita kuni", meaning which (marker) makes "you child this, I say to you, rise" back translation) 
(“Talita kuni”, which means, "you little girl, I say unto you, rise" - my translation)

As mentioned earlier, the second translation foreignises more than the first translation by using italics when presenting the alien word to the target reader. For example:

Ta lita Kumi; itumo eyi ti ise, omobinrin, mo wi fun o, Dide (Mark 5:41)

(Ta lita Kumi; meaning which (marker) makes, girl child, I say to you, Rise - back translation)

(Ta lita Kumi; which means, little girl, I say unto you, Arise - my translation)

Rabbi, (itumo eyi tii ije Olukoni) (John 20:16)

(Rabbi, (meaning which marker means Teacher) - back translation)

(Rabbi, (which means Teacher) - my translation)

Another particular strategy that characterises the third translation is explicitation in the in-text translation. For example:

Kobani ni (eyi nipe ebun fun Olorun ni) (Mark 7:11)

(Kobani is (this is that gift for God is) - back translation)

(It is Kobani (this is, it is a gift for God) - my translation)

Iwo ni Simoni omo Johanu, Kefa ni a o ma pe O (itumo "Kefa" ni "apata", "Peteru” ni ede Giriki) (John 1:42)

(You is Simon child John, Cephas is we will call You (meaning "Cephas" is "Rock", "Peter" is language Greek) - back translation)

(You are Simon son of Jonah, you will be called Cephas (the meaning of "Cephas" is "rock", "Peter" in Greek) - my translation)

Also, the foreign word is omitted in a few instances in the third translation, e.g.

Egbaagbeje ni mo n je, nitori a ko ni iye (Mark 5:9)

(millions is I am answer, because we (neg. marker) have number - back translation) (I am called legion, because we are countless - my translation)

The examples above show that BIA, which has a different source text, is more communicative in its approach than the first two translations. This is actually because the third translation is faithful to its source text, which is why its results are different to the other two translations. It is, however, worth noting that besides the fact that the three translations are source text-oriented and have different source texts, they do not differ much in many of the in-text translations. For example, see the following Yoruba translations for Mark 7:34 and John 1:42:

Mark 7:34:

BMI: Efata, eyini ni, Iwo si

(Efata, that is, You open - back translation)

(Efata, that is, open - my translation) 
BM2: Efata, eyi nni ni, Iwo si

(Efata, that is, You open - back translation)

(Efata, that is, open - my translation)

BIA "Efata", itumo eyi ti ise, "Iwo si"

("Efata", meaning that is makes, "You open" - back translation)

("Efata", which means "open" - my translation)

John 1:42:

BM1: Iwo ni Simoni omo Jona: Kefa li a o si ma pe o, itumo eyi ti ije Peteru (You is Simon child Jonas: Cephas will we will marker will call you, meaning which marker means Peter - back translation)

(You are Simon son of Jonas: You shall be called Cephas, which means Peter my translation)

BM2: Iwo ni Simoni omo Jona: Kefa ni a o si maa pe o, itumo eyi ti ije Peteru (You is Simon child Jonas: Cephas will we will marker will call you, meaning which marker means Peter - back translation)

(You are Simon son of Jonas: You shall be called Cephas, which means Peter my translation)

BIA: Iwo ni Simoni omo Johanu, Kefa ni a oo maa pe o (itumo "Kefa” ni “apata”, "Peteru” ni ede Giriki)

(You is Simon child Jonas, Cephas is we will marker call you (meaning "Cephas" is "rock", "Peter" in language Greek) - back translation)

(You are Simon son of Jonas, you shall be called Cephas (the meaning of "Cephas" is "rock", "Peter" in Greek language - my translation)

From this it is clear that although different source texts are used for the translations, the translations are quite similar, and the differences can be attributed to different source texts.

\section{Divergence and convergence of in-text translations in German and Yoruba Bibles}

The communicative approach evident in the retranslation of the German Bibles and the third Yoruba Bible proves that the RH theory cannot hold true in both cases. It is also clear that the retranslations of the Yoruba Bibles are semantic, while the communicative approach was implemented in the retranslations of the German Bible. The use of these different approaches resulted in a divergence in the transfer of in-text translation in the German Bible and convergence in the Yoruba Bible.

The following criteria are valid in a semantic translation (Munday 2010:45), and are evident in examples of retranslation of the Yoruba Bible discussed above: 1) If the source text language norms deviate, then this must be replicated in the target text; this is a matter of loyalty to source text authors, and 2) Accuracy of reproduction of the significance of the source text. For communicative translation, the following are valid (Munday 2010:45) and are evident in the retranslation of the Bible into German: 1) Smoother, 
simpler, clearer, more direct, more conventional translation, and 2) Respect for the form of the source language, but overriding "loyalty" to target language norms.

From the above, it can be concluded that in-text translations in the German versions of the Bible are more divergent in meaning than in the Yoruba versions, as the retranslations of these words are less similar in the German Bibles than in the Yoruba Bibles - despite the fact that the German versions have the same source texts while the Yoruba Bibles have more than one source text and are retranslations of the English Bible, which are also translations.

\section{BIBLIOGRAPHY}

Achebe, C. 1958, Things Fall Apart. London: Heinemann.

Achebe, C. 1964, Arrow of God. London: Heinemann.

Bandia, P. 1996, Code-switching and code-mixing in African creative writing: Some insights for translation studies, Traduction, Terminologie, Redaction (TTR) 91:139-153.

Bensimon, P. 1990. Présentation, Palimpsestes 4(1):9-13. Available online: http://journals.openedition.org/palimpsestes/728 [Accessed 20/11/2018].

Bibeli Iroyin Ayo. 2013. Lagos: Bible Society of Nigeria.

Bibeli Mimo. 2003. Lagos: Nigeria Bible Society.

Bibeli Mimo. 2006. Apapa: Nigeria Bible Society.

Die Bibel. Hoffnung für Alle. 2002. Vol. 3. Basel und Gießen: Brunnen Verlag.

Die Bibel. Lutherbibel Standardausgabe. 1985. Stuttgart: Deutsche Bibelgesellschaft.

Folsom, M. 1986. Four recent German Bible translations, Deseret Language and

Linguistic Society Symposium (Vol. 12) 1(21):198-212.

Gumperz, J. 1982. Discourse strategies. Cambridge: Cambridge University Press.

Gute Nachricht Bibel. 1997. Stuttgart: Deutsche Bibelgesellschaft.

Iwe Mimo ni Itumo Aye Titun. 1997. Wallkill, New York: Watchtower Bible and Tract Society of New York Inc.

Makutoane, T and Naudé, J. 2009. Colonial interference in the translation of the Bible into Southern Sotho, Acta Theologica Supplementum 12:79-94.

Masubelele, M. 2007. The role of Bible translation in the development of written Zulu: A corpus-based study. $\mathrm{PhD}$ dissertation, University of South Africa.

Munday, J. 2010. Introducing translation studies. Theories and applications. USA and Canada: Routledge.

Newmark, P. 1981. Approaches to translation. Oxford and New York: Pergamon.

Newmark, P. 1988. A textbook of translation. New York and London: Prentice Hall.

Nickel, S. 2013. Spreading which word? Philological, theological and socio-political considerations behind the nineteenth-century Bible translation into Yoruba, Leeds Working Papers in Linguistics and Phonetics (LWPLP) 18:54-84.

Nida, E. 1947. Bible translating. An analysis of principles and procedures. New York: American Bible Society.

Oyali, U. 2018. The retranslation hypothesis and lexical borrowings in Bible translation into Igbo, Lebende Sprachen 63(1):84-100.

Oyebola, M. 2007. Die Übersetzung der Bibel ins Yoruba: Eine kritische Analyse. In Shaban Mayanja (ed.), Beiträge Nigerianischer Germanisten, pp. 64-76. 